Article

\title{
Optimizing Cropping Systems of Cultivated Pastures in the Mountain-Basin Systems in Northwest China
}

\author{
Yao Fan ${ }^{1} \mathbb{1}$, Bo Li ${ }^{1, *}$, Xuhuan Dai ${ }^{1}$, Lingxiao Ma ${ }^{1,2}$, Xiaoli Tai ${ }^{1}$, Xu Bi ${ }^{1,3}$, Zihan Yang ${ }^{1}$ (D) \\ and Xinshi Zhang ${ }^{1,4}$ \\ 1 Faculty of Geographical Science, Beijing Normal University, Beijing 100875, China; \\ fanyao@mail.bnu.edu.cn (Y.F.); daixuhuan@mail.bnu.edu.cn (X.D.); 201521190039@mail.bnu.edu.cn (L.M.); \\ 201731190007@mail.bnu.edu.cn (X.T.); 201531190023@mail.bnu.edu.cn (X.B.); \\ zhyang@mail.bnu.edu.cn (Z.Y.); 03143@bnu.edu.cn (X.Z.) \\ 2 Poverty Alleviation Office, Ministry of Natural Resources of PRC, Beijing 100034, China \\ 3 College of Resources and Environment, Shanxi University of Finance and Economics, Taiyuan 030006, China \\ 4 Institute of Botany, Chinese Academy of Sciences, Beijing 100093, China \\ * Correspondence: libo@bnu.edu.cn; Tel.: +86-10-58807057
}

Received: 9 September 2020; Accepted: 2 October 2020; Published: 4 October 2020

\begin{abstract}
Cultivated pastures are effective supporting systems of natural grassland preservation and sustainable agriculture in arid regions of northwest China. The adaptive combination of forage species enhances the yields and ecological functions of cultivated pastures. Legume-grass intercropping is a valuable sowing regime because of the niche differentiation and resource acquisition. Understanding the effects of species interactions in legume-grass intercropping systems can provide scientific and practical guidance on cultivated pasture management. In this study, we conducted a field experiment to determine the advantages and effects of alfalfa (Medicago sativa L.) annual grass intercropping on cultivated pastures. We analyzed the data on population traits, community characteristics and dry matter in the growing period to evaluate the effects of variety and sowing patterns with the following treatments: three alfalfa varieties (Algonquin, Leafy king, WL354HQ) sown in monocultures and mixed with oat (Avena sativa L.) or sudangrass (Sorghum sudanense (Piper) Stapf.) with two seeding ratios. Our results suggest that in mixtures, the plant traits of alfalfa were determined by their own characters at the earlier stage but were affected more by companion grass at the later stage. The annual forage grass companion impaired the growth of alfalfa during the growth period. In mixtures, sudangrass displayed a stronger inhibiting effect on alfalfa than oat. Alfalfa-grass intercropping was proved to be a feasible cropping practice in terms of yield, production stability and weed control, due to their complementary use of resources in comparison with alfalfa monocropping. Alfalfa-annual grass intercropping is a beneficial alternative strategy to obtain effective cultivated pastures in arid regions.
\end{abstract}

Keywords: alfalfa; sowing pattern; grass-legume intercropping; dynamic feature; community characteristic; mountain-basin systems

\section{Introduction}

Overgrazing and the degradation of natural grassland have been inevitable and represent constraints on husbandry development in the arid regions of northwest China [1]. Changes in grazing regimes, such as grazing exclusion and rotational grazing, have limitations in the conservation and restoration of natural grasslands. The typical vast compound landforms including mountain, oasis and desert in this region were defined as mountain-basin systems (MBS) by Zhang [2]. The MBS comprises interacting subsystems with the exchange of energy, material, life and culture [3]. Cultivated pastures 
in oasis areas were regarded as an essential component of the eco-productive paradigm for ecological restoration and sustainable development in the MBS. Cultivated pasture is also regarded as a proper strategy of restoration for degraded grasslands by carbon sequestration and nitrogen assimilation [4]. Planting forage is an effective method to improve primary productivity [5], thus mitigating grazing pressure on natural grasslands. A low-input forage-based system on small farms with suitable production capacity is essential to improving livestock production and herdsmen's livelihoods.

Alfalfa, or lucerne, is a widely grown perennial legume forage well adapted to drought and can survive extreme environments [6]. In the oasis areas of northern Junggar Basin, alfalfa is currently sown in monocrops for forage production by small-scale herdsmen in a maize-alfalfa rotation system with the utilization of silage or fodder. In arid regions, cultivated pasture is an important support system for the conversion of nomadic livelihood to household settlement, which contributes to labor force liberation. However, the weak growth of alfalfa in the first year leads to a low yield and shortage of forage in autumn and winter [7]. Hence, considering forage production and ecological preservation, there is an urgent need to alter the existing cropping system to develop better intercrop regimes.

Studies on diversified cropping systems and species interactions have been considered as ways to understand how functional diversity affects ecosystem functions and services [8]. The exploration of designing plant communities not only enriches theoretical knowledge about the interactions between plant species but also provides effective functional groups and practical ecosystem management [9]. Intercropping is considered a small-scale potential agricultural land use pattern and arranged combinations of species to develop sustainable agroecosystems by improving land-use efficiency [10]. Increased plant species richness often facilitates productivity, stability, invasion resistance and reduces vulnerability to environmental disturbance [11,12]. Reasonable species configurations and agronomic management result in the high productivity and stability of the agroecosystem [13]. However, designing intercropping systems is complex because of the uncertain interactions between component species, preferences of the local community and the available management practices [14]. Reduced yield may be possible due to the inappropriate arrangement of the component crops and unreasonable practical management. Complex mixtures are not necessarily yielding more than binary mixtures [15]. Thus, the selection of species and proper arrangements for seeding ratios for small households are essential for an efficient intercropping system to capture a greater range of resources.

Planting legumes has been regarded as an important way to promote sustainable and environmentally friendly agricultural practices to meet the growing needs for food and forage production because of the foreseeable rising world population [16]. Legume-grass intercropping is a valuable sowing regime for overyielding because of the niche differentiation in plant traits and resource acquisition $[17,18]$. Reintegrating legume-grass intercrops contributes to more sustainable farming systems [19] and provides environmental benefits such as nutrition restoration, increasing net ecosystem $\mathrm{CO}_{2}$ exchange [20], the accumulation of soil organic carbon [21], and resistance to weed invasion [22]. Legume and grass species affect each other during the vegetation period and constitute a plant community with certain ecological functions. The morphological traits and productivity of forages in the sward for an extended period can be influenced by varieties, sowing ratios and interspecific competition in specific ways $[14,23,24]$. The appearance of the community and the interspecific interactions vary as the plant traits of legume and grass change during the growing season [25]. To date, yield and nutrient valuation are the main interests of researchers in mixed sowing grasslands $[26,27]$. However, there are not enough studies on the effects on alfalfa plant features. Consequently, it is of great value to understand the dynamic relationships between species and the stability of legume-grass intercropping communities. There is limited information available on changes in the population and community characteristics of legume-annual grass mixtures in the establishment year, and differences in various sowing patterns have yet to be analyzed. Such knowledge is essential for understanding the dynamic interactions of legume-grass intercrops and for predicting ecosystem function at the community level. Therefore, it is justified to examine a variety of legume-grass intercrops with observations of changing plant traits and community characteristics to 
discover the optimized combination of species in cultivated pastures. Forage oat (Avena sativa L.) and sudangrass (Sorghum sudanense (Piper) Stapf.) are both high-yield, palatable and drought-resistant annual forage grass species. Recent studies on the intercropping of legumes with oat or sudangrass have mainly focused on yield potential, nutritive value, silage quality and digestibility [28,29]. Less attention has been paid to species interactions with alfalfa in intercrops.

This study's objective was to optimize the cropping systems of cultivated pastures in the mountain-basin systems by assessing the advantages and effects of legume-grass intercropping on cultivated pastures. Thus, we conducted field experiments with binary alfalfa-grass intercrops and alfalfa monocrops throughout a growing period. Our results can help to elucidate strategies in the transition to alfalfa-grass mixed sowing communities. The findings contribute to assessing the optimal combinations of alfalfa-annual grass intercrops and promoting agriculturally relevant ecosystem management in terms of production and ecological functions, especially in arid environments.

\section{Materials and Methods}

\subsection{Study Site}

The experiment was established at the demonstration field of Beijing Normal University located in Hujierte Village of Dure town, Fuyun County, Xinjiang Uygur Autonomous Region, China $\left(46^{\circ} 30^{\prime} 41^{\prime \prime} \mathrm{N}\right.$, $88^{\circ} 28^{\prime} 37^{\prime \prime} \mathrm{E}, 657 \mathrm{~m}$ above sea level). The area has a temperate continental climate with a mean annual temperature of $4.3^{\circ} \mathrm{C}$, and the extreme temperature ranges from $-41.7^{\circ} \mathrm{C}$ in January to $40.6{ }^{\circ} \mathrm{C}$ in July. The annual mean precipitation and potential evaporation are 110 and $2349.6 \mathrm{~mm}$, respectively. The soil is brown calcic soil. The field is located in an oasis area of northern Junggar Basin, $4 \mathrm{~km}$ away from the Ulungur River. Before the experiment was established, the field was previously cultivated and fertilized with forage maize, and it was plowed and leveled before sowing.

\subsection{Experimental Design and Agronomic Management}

The experiment was established in a randomized block design and included 15 treatments with five replicates on 13 May 2018. Each plot was $14 \mathrm{~m} \times 10 \mathrm{~m}$ with an interval of $1 \mathrm{~m}$ between the plots (Figure A1). Three commonly used alfalfa varieties with high drought resistance, cold resistance and pest resistance were sown in monocultures. Each variety was sown with sudangrass or oat at two seeding ratios. The seeding amount of alfalfa in mixtures was two-thirds of the amount in monocultures. The sowing amounts and the abbreviation of each treatment are shown in Table 1. Sudangrass variety "Ningnong" and oat variety "Baicheng" were sown at $5 \mathrm{~cm}$ depth and alfalfa was sown afterward on the corresponding plots at $2 \mathrm{~cm}$ depth, row spacing was $15 \mathrm{~cm}$. The plots were irrigated with furrow irrigation five times approximately every 20 days from May to August. Urea was applied twice and the fertilization rate was $75 \mathrm{~kg} \mathrm{ha}^{-1}$ each time. Other agricultural practices followed conventional field management. During the experiment, the field was enclosed, and no grazing was conducted. Mixtures with sudangrass were harvested on 6 July for the first time. All swards were harvested on 27 August.

Table 1. Seeding amounts and abbreviations of all treatments.

\begin{tabular}{|c|c|c|c|c|c|c|c|c|c|}
\hline \multirow[b]{2}{*}{ Treatments } & \multicolumn{2}{|c|}{ Alfalfa } & \multicolumn{2}{|c|}{ Grass } & \multirow[b]{2}{*}{ Treatments } & \multicolumn{2}{|c|}{ Alfalfa } & \multicolumn{2}{|c|}{ Grass } \\
\hline & Variety & $\begin{array}{c}\text { Amount } \\
\left(\mathrm{kg} \mathrm{ha}^{-1}\right)\end{array}$ & Species & $\begin{array}{c}\text { Amount } \\
\left(\mathrm{kg} \mathrm{ha}^{-1}\right)\end{array}$ & & Variety & $\begin{array}{c}\text { Amount } \\
\left(\mathrm{kg} \mathrm{ha}^{-1}\right)\end{array}$ & Species & $\begin{array}{c}\text { Amount } \\
\left(\mathrm{kg} \mathrm{ha}^{-1}\right)\end{array}$ \\
\hline $\mathrm{AO} 1$ & Algonquin & 30 & Oat & 60 & LO1 & Leafy king & 30 & Oat & 60 \\
\hline $\mathrm{AO} 2$ & Algonquin & 30 & Oat & 80 & $\mathrm{LO} 2$ & Leafy king & 30 & Oat & 80 \\
\hline AS1 & Algonquin & 30 & Sudangrass & 45 & LS1 & Leafy king & 30 & Sudangrass & 45 \\
\hline AS2 & Algonquin & 30 & Sudangrass & 60 & LS2 & Leafy king & 30 & Sudangrass & 60 \\
\hline WO1 & WL354HQ & 30 & Oat & 60 & $\mathrm{AM}$ & Algonquin & 45 & - & - \\
\hline WO2 & WL354HQ & 30 & Oat & 80 & LM & Leafy king & 45 & - & - \\
\hline WS1 & WL354HQ & 30 & Sudangrass & 45 & WM & WL354HQ & 45 & - & - \\
\hline WS2 & WL354HQ & 30 & Sudangrass & 60 & & & & & \\
\hline
\end{tabular}

Note: A, algonquin; L, leafy king; W, WL354HQ. S1 and S2 represent sudangrass at seeding rates of 45 and $60 \mathrm{~kg} \mathrm{ha}^{-1}$, respectively. $\mathrm{O} 1$ and $\mathrm{O} 2$ represent oat at seeding rates of 60 and $80 \mathrm{~kg} \mathrm{ha}^{-1}$, respectively. M means monoculture. The abbreviations of treatments are combinations of variety and sowing pattern. 


\subsection{Sample Processing and Measurements}

Measurements of three randomly selected quadrats $(0.5 \mathrm{~m} \times 0.5 \mathrm{~m})$ were averaged in each plot. Quadrats were established in the middle of each plot at least $2 \mathrm{~m}$ from the edge. All plants were recorded, measured and clipped by species and divided into the following three categories: alfalfa, grass and weed. Sampling and measurements were carried out following a consistent manner three times on 24 June, 28 July and 24 August. Plant height was measured on 10 plant individuals per species within each quadrat. Coverage in percent of ground cover was the mean estimation of three people by a visual method. Individual numbers of each species in the quadrat were counted while clipping. The branch number was counted on five plant individuals per quadrat. Density determination was equal to the total number of individuals divided by the quadrat area. Photosynthetically active radiation (PAR) was observed by a plant canopy analyzer (TOP-1000) with five scans at the canopy height of alfalfa in each quadrat from 1 p.m. to 2 p.m. without cloud interference.

After measuring, plants were hand-harvested at $2 \mathrm{~cm}$ above the ground level and collected by species. All unseeded species were classified as weeds. Samples were dried at $80^{\circ} \mathrm{C}$ with air ventilation until reaching a constant weight to estimate the aboveground dry matter biomass. We used $S(S=\mu / \sigma)$ to measure the productivity stability of the plant community during each period [30]. In the formula, $\mu$ and $\sigma$ represent the average and standard deviation of the dry matter biomass (DM) in each community, respectively. If there was no variation at all $(\sigma=0), S$ would be maximal. When the variation is larger than the mean, $S$ is smaller. Therefore, a larger value of $S$ indicates higher productivity stability.

\subsection{Statistical Analysis}

Statistical analyses were performed using SPSS version 20.0. Tests for normality and equality of variances were conducted prior to the analysis. Analysis of variance (ANOVA) was performed to analyze the effects of variety and sowing pattern on the population features of alfalfa, community characteristics and DM. Duncan's multiple range test was used to separate the means of treatments at the level of $p<0.05$. Dunnett's T3 test was used when the variances between treatments were not equal. Figures were plotted in Origin Pro 2015.

\section{Results}

\subsection{Dry Matter Biomass}

Table 2 shows the alfalfa DM and total DM among the growth period. Alfalfa DM in monocultures were significantly greater than in mixtures for the same variety, except for AM in August. Alfalfa DM were not significantly different among mixtures for the same growth variety in each period. With respect to total DM, DM in mixtures with sudangrass was significantly greater than in monocultures for the same variety in June (Table 2; Figure A2). Mixtures with oat showed no significant DM difference with monocultures. In July, mixtures with oat had a significantly greater DM than mixtures with sudangrass (Table 2; Figure A2). However, the DM among all treatments was not significantly different in August. 
Table 2. Alfalfa dry mass (DM) and the total DM of all treatments during the growing season.

\begin{tabular}{|c|c|c|c|c|c|c|}
\hline \multirow{2}{*}{ Period } & \multirow{2}{*}{ Variety } & \multicolumn{5}{|c|}{ Sowing Patterns } \\
\hline & & O1 & $\mathrm{O} 2$ & S1 & S2 & $\mathbf{M}$ \\
\hline \multicolumn{7}{|c|}{ Alfalfa DM $\left(\mathrm{g} \mathrm{m}^{-2}\right)$} \\
\hline \multirow{4}{*}{ June } & $\mathrm{A}$ & $5.0 \pm 2.5 \mathrm{ab}$ & $6.1 \pm 2.8 \mathrm{ab}$ & $8.3 \pm 6.0 \mathrm{abc}$ & $5.4 \pm 3.0 \mathrm{ab}$ & $18.7 \pm 5.2 \mathrm{~d}$ \\
\hline & W & $17.0 \pm 11.6 \mathrm{~cd}$ & $4.6 \pm 3.0 \mathrm{a}$ & $7.0 \pm 3.9 \mathrm{ab}$ & $9.0 \pm 2.1 \mathrm{abc}$ & $48.8 \pm 9.4 \mathrm{f}$ \\
\hline & $\mathrm{L}$ & $18.9 \pm 4.0 \mathrm{~d}$ & $14.8 \pm 9.1 \mathrm{bcd}$ & $14.4 \pm 10.9 \mathrm{abcd}$ & $13.4 \pm 4.7 \mathrm{abcd}$ & $35.8 \pm 8.3 \mathrm{e}$ \\
\hline & A & $16.2 \pm 6.5 \mathrm{ab}$ & $20.6 \pm 5.0 a b c$ & $8.5 \pm 5.9 \mathrm{a}$ & $9.5 \pm 3.6 \mathrm{a}$ & $72.2 \pm 34.9 \mathrm{~d}$ \\
\hline \multirow[t]{3}{*}{ July } & $\mathrm{W}$ & $39.0 \pm 15.6 \mathrm{bc}$ & $25.1 \pm 14.1 \mathrm{abc}$ & $20.5 \pm 12.5 \mathrm{abc}$ & $20.1 \pm 9.0 \mathrm{abc}$ & $150.4 \pm 24.5 \mathrm{e}$ \\
\hline & $\mathrm{L}$ & $44.0 \pm 17.0 \mathrm{c}$ & $45.4 \pm 15.2 \mathrm{c}$ & $24.8 \pm 13.5 \mathrm{abc}$ & $21.3 \pm 5.3 \mathrm{abc}$ & $182.4 \pm 22.1 \mathrm{f}$ \\
\hline & A & $28.5 \pm 14.1 \mathrm{abc}$ & $28.5 \pm 9.0 \mathrm{abc}$ & $14.4 \pm 2.3 \mathrm{a}$ & $5.0 \pm 2.6 \mathrm{a}$ & $54.4 \pm 12.9 \mathrm{bcd}$ \\
\hline \multirow[t]{2}{*}{ August } & W & $61.1 \pm 15.9 \mathrm{~cd}$ & $33.0 \pm 11.4 \mathrm{abc}$ & $22.1 \pm 15.2 \mathrm{ab}$ & $25.1 \pm 6.1 \mathrm{ab}$ & $143.8 \pm 33.5 \mathrm{e}$ \\
\hline & $\mathrm{L}$ & $78.1 \pm 38.2 \mathrm{~d}$ & $68.6 \pm 30.0 \mathrm{~d}$ & $23.7 \pm 12.0 \mathrm{ab}$ & $30.2 \pm 14.0 \mathrm{abc}$ & $244.8 \pm 56.7 \mathrm{f}$ \\
\hline \multicolumn{7}{|c|}{ Total DM $\left(\mathrm{g} \mathrm{m}^{-2}\right)$} \\
\hline \multirow{4}{*}{ June } & $\mathrm{A}$ & $95.7 \pm 26.7$ cde & $91.4 \pm 20.1 \mathrm{cde}$ & $124.5 \pm 18.7 \mathrm{bc}$ & $106.9 \pm 48.0 \mathrm{bcd}$ & $47.5 \pm 13.6 \mathrm{e}$ \\
\hline & $\mathrm{W}$ & $94.6 \pm 12.2$ cde & $97.8 \pm 52.8$ bcde & $184.4 \pm 70.5 \mathrm{a}$ & $152.6 \pm 62.2 \mathrm{ab}$ & $104.2 \pm 24.7 \mathrm{bcd}$ \\
\hline & $\mathrm{L}$ & $93.7 \pm 15.7 \mathrm{cde}$ & $105.5 \pm 10.8 \mathrm{bcd}$ & $145.8 \pm 28.7 \mathrm{abc}$ & $147.8 \pm 63.5 \mathrm{abc}$ & $61.4 \pm 15.9$ de \\
\hline & A & $408.3 \pm 37.3 \mathrm{a}$ & $271.4 \pm 60.7$ cde & $188.6 \pm 61.0 \mathrm{e}$ & $189.9 \pm 46.2 \mathrm{e}$ & $313.6 \pm 80.8 \mathrm{bcd}$ \\
\hline \multirow[t]{3}{*}{ July } & W & $375.2 \pm 67.3 \mathrm{ab}$ & $348.6 \pm 161.1 \mathrm{abc}$ & $189.4 \pm 41.9 \mathrm{e}$ & $212.2 \pm 42.4 \mathrm{e}$ & $310.4 \pm 80.0 \mathrm{bcd}$ \\
\hline & $\mathrm{L}$ & $356.6 \pm 48.9 \mathrm{abc}$ & $425.6 \pm 49.8 \mathrm{a}$ & $232.5 \pm 25.8 \mathrm{de}$ & $198.7 \pm 41.8 \mathrm{e}$ & $222.4 \pm 41.6 \mathrm{de}$ \\
\hline & A & $358.6 \pm 51.4 \mathrm{abc}$ & $399.7 \pm 101.3 \mathrm{a}$ & $382.7 \pm 100.0 \mathrm{a}$ & $313.4 \pm 86.1 \mathrm{abc}$ & $253.3 \pm 66.9 \mathrm{c}$ \\
\hline \multirow[t]{2}{*}{ August } & W & $351.2 \pm 52.6 \mathrm{abc}$ & $303.4 \pm 104.5 \mathrm{abc}$ & $267.5 \pm 59.2 \mathrm{bc}$ & $266.9 \pm 25.1 b c$ & $313.4 \pm 69.9 \mathrm{abc}$ \\
\hline & $\mathrm{L}$ & $369.9 \pm 45.5 \mathrm{ab}$ & $310.4 \pm 50.9 \mathrm{abc}$ & $302.7 \pm 78.9 \mathrm{abc}$ & $332.3 \pm 98.2 \mathrm{abc}$ & $331.0 \pm 45.6 \mathrm{abc}$ \\
\hline
\end{tabular}

Note: data are the means \pm standard deviation. Within each period, the values followed by different letters are significantly different $(p<0.05)$. A, algonquin; L, leafy king; W, WL354HQ. S1 and S2 represent sudangrass at seeding rates of 45 and $60 \mathrm{~kg} \mathrm{ha}^{-1}$, respectively. $\mathrm{O} 1$ and $\mathrm{O} 2$ represent oat at seeding rates of 60 and $80 \mathrm{~kg} \mathrm{ha}^{-1}$, respectively. M means monoculture.

In the monocultures, leafy king monoculture (LM) had the highest DM proportion followed by WL354HQ monoculture (WM), and algonquin monoculture (AM) had the lowest proportion at the same period. The proportion of weeds in AM and WM increased from $55.8 \%$ to $77.4 \%$ and from $49.9 \%$ to $53.7 \%$ during the period, respectively (Figure 1). No significant difference in weed density was detected among the monocultures during the period. For all the mixtures, the grass species had the vast majority of DM proportions ranging from $46.7 \%$ to $94.6 \%$ during the period (Figure 1). In general, the DM proportion of alfalfa did not vary greatly during the period. The proportion of weed tended to increase while the proportion of grass had the opposite tendency. In particular, the proportions of weed in mixtures with sudangrass were lower than those in mixtures with oat for the same variety (Figure 1).

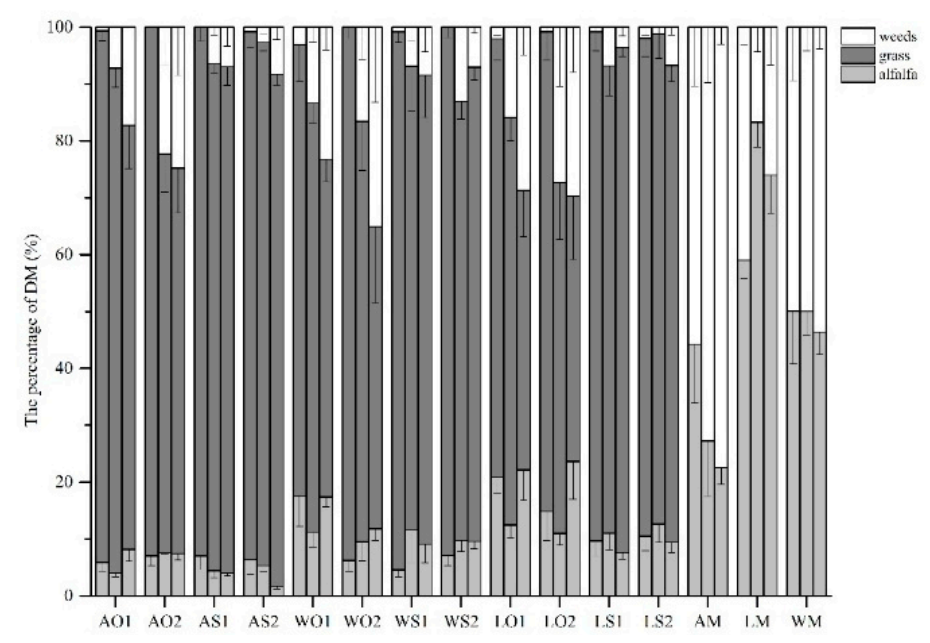

Figure 1. The percentage of DM among all treatments during the growing season (mean $\pm \mathrm{SE}$ ). The three columns in each treatment represent the DM proportions of June, July and August, respectively. The abbreviations are the same as above. 


\subsection{Population Features of Alfalfa}

The plant heights of alfalfa were all higher in monocultures than in mixtures during the growing season for the same variety (Table 3). In all monocultures, AM had the lowest plant height, LM had the highest plant height in June and WM had the highest plant height in July and August. In June and July, there were no significantly different plant heights between LM and WM. However, the plant heights in the three monocultures were significantly different in August (Table 3).

Table 3. Plant height, branch number and plant density of alfalfa in all treatments.

\begin{tabular}{|c|c|c|c|c|c|c|}
\hline \multirow{2}{*}{ Period } & \multirow{2}{*}{ Variety } & \multicolumn{5}{|c|}{ Sowing patterns } \\
\hline & & 01 & $\mathrm{O} 2$ & S1 & S2 & $\mathbf{M}$ \\
\hline \multicolumn{7}{|c|}{ Plant Height (cm) } \\
\hline \multirow{3}{*}{ June } & A & $6.9 \pm 20.5 f$ & $7.0 \pm 0.9 \mathrm{f}$ & $9.2 \pm 1.7$ ef & $7.8 \pm 1.4 \mathrm{f}$ & $18.1 \pm 1.7 b$ \\
\hline & $\mathrm{W}$ & $13.9 \pm 1.7 \mathrm{c}$ & $8.4 \pm 1.4$ ef & $12.6 \pm 1.1 \mathrm{~cd}$ & $12.9 \pm 2.7 \mathrm{~cd}$ & $21.4 \pm 2.7 \mathrm{a}$ \\
\hline & $\mathrm{L}$ & $13.3 \pm 1.0 \mathrm{~cd}$ & $10.7 \pm 1.2 \mathrm{de}$ & $12.2 \pm 2.4 \mathrm{c}$ & $18.1 \pm 1.7 \mathrm{~b}$ & $22.4 \pm 1.4 \mathrm{a}$ \\
\hline \multirow{3}{*}{ July } & A & $17.1 \pm 1.8 \mathrm{def}$ & $18.5 \pm 2.5 \mathrm{de}$ & $9.9 \pm 2.3 \mathrm{~h}$ & $10.4 \pm 1.4 \mathrm{gh}$ & $29.9 \pm 3.4 b$ \\
\hline & W & $21.3 \pm 4.7 \mathrm{~cd}$ & $20.8 \pm 5.8 \mathrm{~cd}$ & $13.8 \pm 2.1 \mathrm{efgh}$ & $15.1 \pm 2.3 \mathrm{efg}$ & $40.5 \pm 6.2 \mathrm{a}$ \\
\hline & $\mathrm{L}$ & $20.7 \pm 3.6 \mathrm{~cd}$ & $24.0 \pm 1.9 \mathrm{c}$ & $13.0 \pm 3.5 \mathrm{fgh}$ & $16.3 \pm 3.5 \mathrm{def}$ & $38.3 \pm 3.7 \mathrm{a}$ \\
\hline \multirow{3}{*}{ August } & A & $25.1 \pm 3.4 \mathrm{c}$ & $24.3 \pm 4.3 c$ & $16.0 \pm 1.4 \mathrm{e}$ & $15.0 \pm 1.8 \mathrm{e}$ & $26.5 \pm 3.2 c$ \\
\hline & W & $26.6 \pm 2.7 c$ & $26.7 \pm 3.4 c$ & $22.5 \pm 4.4 \mathrm{~cd}$ & $18.0 \pm 5.0 \mathrm{e}$ & $41.6 \pm 5.2 \mathrm{a}$ \\
\hline & $\mathrm{L}$ & $24.7 \pm 2.6 \mathrm{c}$ & $22.3 \pm 1.3 \mathrm{~cd}$ & $15.2 \pm 3.1 \mathrm{e}$ & $19.0 \pm 1.5 \mathrm{de}$ & $36.6 \pm 2.3 b$ \\
\hline \multicolumn{7}{|c|}{ Branch Number } \\
\hline \multirow{4}{*}{ June } & $\mathrm{A}$ & $4.4 \pm 0.7$ ef & $4.5 \pm 0.8 \mathrm{def}$ & $4.4 \pm 0.5 \mathrm{f}$ & $5.8 \pm 1.0 \mathrm{~b}$ & $7.4 \pm 0.2 \mathrm{a}$ \\
\hline & W & $5.0 \pm 0.8$ bcdef & $4.9 \pm 0.4$ bcdef & $4.8 \pm 0.7 \mathrm{cdef}$ & $5.0 \pm 0.7$ bcdef & $7.2 \pm 0.2 \mathrm{a}$ \\
\hline & $\mathrm{L}$ & $5.6 \pm 0.3 \mathrm{bc}$ & $5.4 \pm 0.5 \mathrm{bcd}$ & $5.0 \pm 0.6$ bcdef & $5.3 \pm 0.9$ bcde & $7.9 \pm 0.5 \mathrm{a}$ \\
\hline & A & $7.8 \pm 1.2$ cde & $9.0 \pm 2.0 \mathrm{~cd}$ & $5.9 \pm 1.6 \mathrm{e}$ & $6.4 \pm 1.1 \mathrm{e}$ & $11.9 \pm 0.8 \mathrm{ab}$ \\
\hline \multirow[t]{2}{*}{ July } & W & $8.9 \pm 2.9 \mathrm{~cd}$ & $9.0 \pm 2.5 \mathrm{~cd}$ & $6.2 \pm 0.6 \mathrm{e}$ & $7.5 \pm 2.0 \mathrm{de}$ & $11.7 \pm 1.6 \mathrm{ab}$ \\
\hline & $\mathrm{L}$ & $10.0 \pm 2.3 b c$ & $9.6 \pm 0.9 \mathrm{bcd}$ & $6.2 \pm 1.7 \mathrm{e}$ & $6.4 \pm 0.4 \mathrm{e}$ & $13.4 \pm 1.7 \mathrm{a}$ \\
\hline \multirow{3}{*}{ August } & A & $10.2 \pm 1.6 \mathrm{ab}$ & $11.2 \pm 3.2 \mathrm{a}$ & $7.4 \pm 1.1 \mathrm{~cd}$ & $6.5 \pm 1.0 \mathrm{~d}$ & $10.3 \pm 2.0 \mathrm{ab}$ \\
\hline & W & $10.8 \pm 2.2 \mathrm{a}$ & $9.8 \pm 0.9 \mathrm{abc}$ & $7.5 \pm 0.9 \mathrm{~cd}$ & $7.1 \pm 1.4 \mathrm{~d}$ & $12.0 \pm 1.8 \mathrm{a}$ \\
\hline & $\mathrm{L}$ & $10.9 \pm 0.8 \mathrm{a}$ & $10.5 \pm 2.5 \mathrm{a}$ & $7.6 \pm 1.6 \mathrm{~cd}$ & $8.1 \pm 0.3 \mathrm{bcd}$ & $12.0 \pm 1.2 \mathrm{a}$ \\
\hline \multicolumn{7}{|c|}{ Plant Density (No. of Plants $\mathrm{m}^{-2}$ ) } \\
\hline \multirow{3}{*}{ June } & A & $253.6 \pm 126.7 \mathrm{bc}$ & $242.4 \pm 50.4 \mathrm{bc}$ & $266.4 \pm 170.1 b c$ & $128.0 \pm 77.1 \mathrm{c}$ & $318.4 \pm 107.7 \mathrm{bc}$ \\
\hline & W & $354.4 \pm 213.6 \mathrm{ab}$ & $203.2 \pm 155.5 \mathrm{bc}$ & $211.2 \pm 115.6 \mathrm{bc}$ & $181.6 \pm 56.0 \mathrm{bc}$ & $528.8 \pm 128.4 \mathrm{a}$ \\
\hline & $\mathrm{L}$ & $342.4 \pm 67.1 \mathrm{ab}$ & $392.8 \pm 306.5 \mathrm{ab}$ & $268.8 \pm 108.3 b c$ & $297.6 \pm 122.6 b c$ & $366.4 \pm 60.8 \mathrm{ab}$ \\
\hline \multirow{3}{*}{ July } & A & $296.0 \pm 160.9 b$ & $385.6 \pm 50.4 b$ & $340.8 \pm 201.4 b$ & $656.8 \pm 555.1 \mathrm{ab}$ & $624.0 \pm 192.0 \mathrm{ab}$ \\
\hline & W & $516.8 \pm 281.4 \mathrm{ab}$ & $233.6 \pm 131.9 \mathrm{~b}$ & $446.4 \pm 493.2 \mathrm{ab}$ & $481.6 \pm 335.5 \mathrm{ab}$ & $812.8 \pm 362.5 \mathrm{a}$ \\
\hline & $\mathrm{L}$ & $617.6 \pm 203.8 \mathrm{ab}$ & $566.4 \pm 112.2 \mathrm{ab}$ & $379.2 \pm 255.8 \mathrm{~b}$ & $540.8 \pm 207.2 \mathrm{ab}$ & $846.4 \pm 183.5 \mathrm{a}$ \\
\hline \multirow{3}{*}{ August } & A & $377.6 \pm 208.7$ cde & $312.0 \pm 131.2$ cde & $388.8 \pm 85.5$ bcde & $158.4 \pm 66.8 \mathrm{e}$ & $409.6 \pm 191.8$ bcde \\
\hline & $\mathrm{W}$ & $483.2 \pm 191.1$ bcde & $283.2 \pm 144.2 \mathrm{de}$ & $280.0 \pm 111.7 \mathrm{de}$ & $436.8 \pm 195.0$ bcde & $651.2 \pm 392.6 \mathrm{bc}$ \\
\hline & $\mathrm{L}$ & $636.8 \pm 371.4 \mathrm{bcd}$ & $736.0 \pm 399.2 \mathrm{~b}$ & $422.4 \pm 86.1$ bcde & $638.4 \pm 350.7 \mathrm{bcd}$ & $1369.6 \pm 242.6 a$ \\
\hline
\end{tabular}

Note: data are the means \pm standard deviation. Within each period, the values without common letters are significantly different $(p<0.05)$. A, algonquin; L, leafy king; W, WL354HQ. S1 and S2 represent sudangrass at seeding rates of 45 and $60 \mathrm{~kg} \mathrm{ha}^{-1}$, respectively. O1 and $\mathrm{O} 2$ represent oat at seeding rates of 60 and $80 \mathrm{~kg} \mathrm{ha}^{-1}$, respectively. $\mathrm{M}$ means monoculture.

There was no significant difference in the mixtures for the same variety except for WL354HQ-oat at a seeding rate of $80 \mathrm{~kg} \mathrm{ha}^{-1}$ (WO2), leafy king-oat at a seeding rate of $80 \mathrm{~kg} \mathrm{ha}^{-1}$ (LO2) and leafy king-sudangrass at a seeding rate of $60 \mathrm{~kg} \mathrm{ha}^{-1}$ (LS2) in June. The plant heights in mixtures with algonquin (A) were lower than those with WL354HQ (W) and leafy king (L) for the same sowing pattern, the same as found in monocultures. However, the differences became insignificant at the later stage (Table 3). For the same variety in July and August, the plant height was significantly higher in mixtures with oat than in mixtures with sudangrass except for LS2 (Table 3). No significant difference was found between seeding ratios.

The data in Table 3 show that LM had the highest branch number, while the lowest branch number was obtained with algonquin-sudangrass at a seeding rate of $45 \mathrm{~kg} \mathrm{ha}^{-1}$ (AS1) in June and July and with algonquin-sudangrass at a seeding rate of $60 \mathrm{~kg} \mathrm{ha}^{-1}$ (AS2) in August. In June and July, the branch numbers in monocultures were significantly higher than those in mixtures. The branch numbers in mixtures with oat were higher than those with sudangrass in July but were not significantly different in June. In August, there was no significant difference between monocultures and mixtures with oat 
for the same variety. However, the branch numbers in mixtures with oat and monocultures were both significantly higher than those in mixtures with sudangrass (Table 3 ).

The plant density of alfalfa in the mixtures was generally lower than that in monocultures for the same variety except LO2 in June and AS2 in July (Table 3). The highest plant density was obtained with WM in June and LM in July and August. However, the lowest plant density was achieved with mixtures with $\mathrm{A}$, and the plant density was also the lowest in monocultures when compared with $\mathrm{W}$ and L. Besides, no significant difference was observed among the mixtures in the same period (Table 3).

\subsection{Community Characteristics}

Table 4 shows the PAR in the alfalfa canopy for all treatments at different times. In June, the highest PAR occurred in AM, and the lowest PAR occurred in LS2. For A, PAR in AS1 and AS2 were significantly lower than in algonquin-oat at a seeding rate of $60 \mathrm{~kg} \mathrm{ha}^{-1}$ (AO1), algonquin-oat at a seeding rate of $80 \mathrm{~kg} \mathrm{ha}^{-1}(\mathrm{AO} 2)$ and AM. For W and L, alfalfa in mixtures with oat received more PAR than with sudangrass (Table 4). In July, PAR in AM and mixtures with A showed no significant difference. In contrast, for W and L, PAR in mixtures were lower than in monocultures (Table 4). In August, no significant difference was obtained between the mixtures and monocultures for the same variety with respect to PAR.

Table 4. Photosynthetically active radiation (PAR) and community density of all treatments during the growing season.

\begin{tabular}{|c|c|c|c|c|c|c|}
\hline \multirow{2}{*}{ Period } & \multirow{2}{*}{ Variety } & \multicolumn{5}{|c|}{ Sowing Patterns } \\
\hline & & O1 & $\mathrm{O} 2$ & S1 & S2 & $\mathbf{M}$ \\
\hline \multicolumn{7}{|c|}{ PAR $\left(\mu \mathrm{mol} \mathrm{m} \mathrm{m}^{-2} \mathrm{~s}^{-1}\right)$} \\
\hline \multirow{4}{*}{ June } & $\mathrm{A}$ & $248.7 \pm 68.8 \mathrm{ab}$ & $301.9 \pm 39.2 \mathrm{a}$ & $168.4 \pm 30.5$ cdefg & $152.4 \pm 48.7 \mathrm{efg}$ & $306.9 \pm 93.8 \mathrm{a}$ \\
\hline & W & $239.0 \pm 46.2 \mathrm{abc}$ & $206.6 \pm 36.4$ bcdef & $129.8 \pm 64.7 \mathrm{fg}$ & $143.7 \pm 34.2 \mathrm{efg}$ & $217.3 \pm 63.7$ bcde \\
\hline & $\mathrm{L}$ & $215.8 \pm 35.2$ bcde & $233.3 \pm 81.3 \mathrm{abcd}$ & $158.6 \pm 45.8$ defg & $98.9 \pm 13.4 \mathrm{~g}$ & $213.4 \pm 49.6$ bcde \\
\hline & $\mathrm{A}$ & $143.4 \pm 13.1$ bcde & $197.7 \pm 40.6 \mathrm{a}$ & $153.8 \pm 26.6 \mathrm{bcd}$ & $171.7 \pm 22.5 \mathrm{ab}$ & $161.6 \pm 36.2 \mathrm{abc}$ \\
\hline \multirow[t]{3}{*}{ July } & W & $141.3 \pm 36.6$ bcdef & $120.5 \pm 16.4$ cdefg & $116.2 \pm 32.8 \mathrm{defg}$ & $99.6 \pm 11.6 \mathrm{fg}$ & $157.8 \pm 49.4 \mathrm{bcd}$ \\
\hline & $\mathrm{L}$ & $120.4 \pm 21.3 \mathrm{cdefg}$ & $103.1 \pm 32.2 \mathrm{efg}$ & $108.0 \pm 27.3 \mathrm{efg}$ & $79.3 \pm 8.4 \mathrm{~g}$ & $139.8 \pm 17.8$ bcdef \\
\hline & $\mathrm{A}$ & $531.9 \pm 65.9 \mathrm{ab}$ & $371.5 \pm 68.7 \mathrm{~cd}$ & $443.5 \pm 66.6$ bcd & $341.7 \pm 89.1 \mathrm{~cd}$ & $411.4 \pm 21.8 \mathrm{bcd}$ \\
\hline \multirow[t]{2}{*}{ August } & W & $370.2 \pm 100.1 \mathrm{~cd}$ & $568.4 \pm 120.9 \mathrm{a}$ & $322.3 \pm 55.2 \mathrm{~d}$ & $462.0 \pm 77.6 \mathrm{abc}$ & $338.7 \pm 142.1 \mathrm{~cd}$ \\
\hline & $\mathrm{L}$ & $378.2 \pm 63.5 \mathrm{~cd}$ & $572.4 \pm 135.8 \mathrm{a}$ & $316.3 \pm 45.3 \mathrm{~d}$ & $425.8 \pm 81.7 \mathrm{bcd}$ & $511.1 \pm 80.9 \mathrm{ab}$ \\
\hline \multicolumn{7}{|c|}{ Community Density (No. of Plants $\mathrm{m}^{-2}$ ) } \\
\hline \multirow{4}{*}{ June } & $\mathrm{A}$ & $736.8 \pm 109.0 \mathrm{abc}$ & $766.4 \pm 106.1 \mathrm{ab}$ & $626.4 \pm 87.6$ bcde & $450.4 \pm 139.3 \mathrm{e}$ & $524.0 \pm 131.0 \mathrm{cde}$ \\
\hline & W & $892.0 \pm 253.2 a$ & $749.6 \pm 175.1 \mathrm{abc}$ & $496.0 \pm 169.2 \mathrm{de}$ & $520.0 \pm 84.6 \mathrm{cde}$ & $872.8 \pm 102.7 \mathrm{a}$ \\
\hline & $\mathrm{L}$ & $716.8 \pm 144.7 \mathrm{abcd}$ & $877.6 \pm 216.1 \mathrm{a}$ & $630.4 \pm 169.7$ bcde & $637.6 \pm 255.3$ bcde & $587.2 \pm 110.3$ bcde \\
\hline & A & $976.0 \pm 247.3 b$ & $904.0 \pm 97.8 \mathrm{~b}$ & $1507.2 \pm 437.5 \mathrm{ab}$ & $1305.6 \pm 656.3 \mathrm{ab}$ & $881.6 \pm 156.2 b$ \\
\hline \multirow[t]{2}{*}{ July } & W & $1120.0 \pm 264.6 \mathrm{ab}$ & $926.4 \pm 289.7 b$ & $1364.8 \pm 421.6 \mathrm{ab}$ & $1147.2 \pm 424.5 \mathrm{ab}$ & $988.8 \pm 356.5 b$ \\
\hline & $\mathrm{L}$ & $1240.0 \pm 185.5 \mathrm{ab}$ & $1267.2 \pm 220.4 \mathrm{ab}$ & $1310.4 \pm 364.9 \mathrm{ab}$ & $1153.6 \pm 211.2 \mathrm{ab}$ & $896.0 \pm 201.2 b$ \\
\hline \multirow{3}{*}{ August } & A & $1155.2 \pm 268.1 \mathrm{abc}$ & $1036.8 \pm 215.6$ bcde & $980.8 \pm 206.8$ bcde & $724.8 \pm 137.7 \mathrm{de}$ & $696.0 \pm 192.8 \mathrm{e}$ \\
\hline & W & $1192.0 \pm 307.4 \mathrm{abc}$ & $872.0 \pm 227.4$ cde & $918.4 \pm 356.1$ cde & $912.0 \pm 153.4$ cde & $864.0 \pm 428.4$ cde \\
\hline & $\mathrm{L}$ & $1208.0 \pm 246.3 \mathrm{abc}$ & $1332.8 \pm 239.4 \mathrm{ab}$ & $980.8 \pm 137.2$ bcde & $1096.0 \pm 341.8 \mathrm{abcd}$ & $1452.8 \pm 230.4 \mathrm{a}$ \\
\hline
\end{tabular}

Note: data are the means \pm standard deviation. Within each period, the values followed by different letters are significantly different $(p<0.05)$. A, algonquin; L, leafy king; W, WL354HQ. S1 and S2 represent sudangrass at seeding rates of 45 and $60 \mathrm{~kg} \mathrm{ha}^{-1}$, respectively. O1 and O2 represent oat at seeding rates of 60 and $80 \mathrm{~kg} \mathrm{ha}^{-1}$, respectively. $\mathrm{M}$ means monoculture.

Grass coverage in percent ground cover represented from $60.9 \%$ to $96.4 \%$ of the mixtures in June and July (Figure 2). The proportion of grass declined with time, whereas the proportion of alfalfa and weeds tended to increase. For mixtures within the same variety, the coverage proportion of sudangrass was higher than that of oat. Meanwhile, the coverage proportion of alfalfa in mixtures with oat was higher than that with sudangrass at the same period (Figure 2). The performances of different sowing ratios were similar. In monocultures, the coverage proportion of LM was the highest, followed by WM and AM during the same period. The coverage proportion of the three alfalfa varieties peaked in July. 


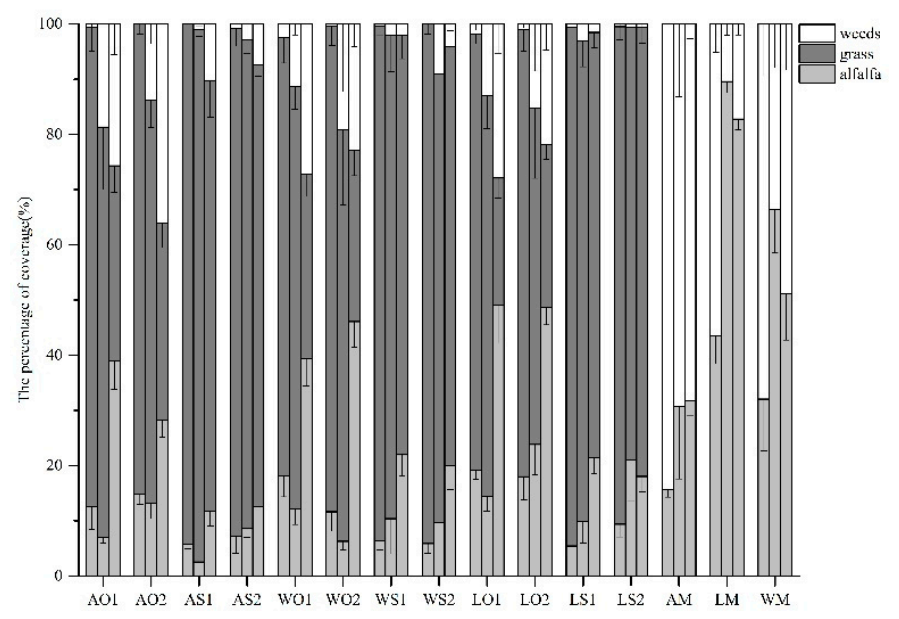

Figure 2. The percentage of coverage among all treatments during the growing season (mean $\pm \mathrm{SE}$ ). The three columns in each treatment represent the coverage proportion of June, July and August. The abbreviations are the same as above.

As shown in Table 4 and Figure A3, the community density in mixtures with oat increased with the growing period, except for leafy king-oat at a seeding rate of $60 \mathrm{~kg} \mathrm{ha}^{-1}$ (LO1) and WO2. The community density in mixtures with sudangrass increased in July and then decreased in August. No significant difference was observed among the mixtures in the same period with the respect to community density.

The greatest productivity stability at different periods was obtained in LO2, AO1 and WL354HQ-sudangrass at a seeding rate of $60 \mathrm{~kg} \mathrm{ha}^{-1}$ (WS2) (Table 5). All the lowest stabilities occurred with WO2. The productivity stability in WO2, WL354HQ-sudangrass at a seeding rate of $45 \mathrm{~kg} \mathrm{ha}^{-1}$ (WS1), WS2, LO1 and LM increased during the growing period. The average stability of the mixtures was improved by $18.2 \%, 32.6 \%$ and $3.9 \%$ compared with the monocultures in June, July and August, respectively.

Table 5. Productivity stability of all communities during the growing period.

\begin{tabular}{ccccccccc}
\hline Treatments & AO1 & AO2 & AS1 & AS2 & WO1 & WO2 & WS1 & WS2 \\
\hline June & $3.6 \pm 0.4$ & $4.6 \pm 0.8$ & $6.7 \pm 1.4$ & $2.2 \pm 0.8$ & $7.7 \pm 1.6$ & $1.9 \pm 0.6$ & $2.6 \pm 0.7$ & $2.5 \pm 0.3$ \\
July & $10.9 \pm 1.7$ & $4.5 \pm 0.7$ & $3.1 \pm 1.0$ & $4.1 \pm 0.8$ & $5.6 \pm 0.6$ & $2.2 \pm 1.1$ & $4.5 \pm 1.0$ & $5.0 \pm 1.4$ \\
August & $7.0 \pm 1.5$ & $3.9 \pm 0.8$ & $3.8 \pm 1.0$ & $3.6 \pm 1.3$ & $6.7 \pm 1.6$ & $2.9 \pm 1.4$ & $4.5 \pm 0.8$ & $10.6 \pm 1.6$ \\
Average & $7.2 \pm 0.4$ & $4.3 \pm 0.6$ & $4.5 \pm 1.1$ & $3.3 \pm 0.4$ & $6.7 \pm 0.7$ & $2.3 \pm 0.3$ & $3.9 \pm 0.3$ & $6.0 \pm 0.3$ \\
\hline Treatments & LO1 & LO2 & LS1 & LS2 & AM & LM & WM & \\
\hline June & $6.0 \pm 1.2$ & $9.8 \pm 1.0$ & $5.1 \pm 1.2$ & $2.3 \pm 0.7$ & $3.5 \pm 0.4$ & $3.9 \pm 0.7$ & $4.2 \pm 0.7$ & \\
July & $7.3 \pm 1.5$ & $8.6 \pm 1.7$ & $9.0 \pm 0.4$ & $4.8 \pm 1.2$ & $3.9 \pm 0.6$ & $5.3 \pm 0.8$ & $3.9 \pm 0.9$ & \\
August & $8.1 \pm 1.5$ & $6.1 \pm 1.5$ & $3.8 \pm 1.0$ & $3.4 \pm 0.7$ & $3.8 \pm 1.1$ & $7.3 \pm 1.2$ & $4.5 \pm 0.7$ & \\
Average & $7.1 \pm 1.1$ & $8.1 \pm 0.7$ & $6.0 \pm 0.8$ & $3.5 \pm 0.2$ & $3.7 \pm 0.6$ & $5.5 \pm 0.3$ & $4.2 \pm 0.6$ & \\
\hline
\end{tabular}

Note: data are the means \pm standard deviation. A, algonquin; L, leafy king; W, WL354HQ. S1 and S2 represent sudangrass at seeding rates of 45 and $60 \mathrm{~kg} \mathrm{ha}^{-1}$, respectively. $\mathrm{O} 1$ and $\mathrm{O} 2$ represent oat at seeding rates of 60 and $80 \mathrm{~kg} \mathrm{ha}^{-1}$, respectively. M means monoculture. The abbreviations of treatments are combinations of variety and sowing pattern.

\section{Discussion}

\subsection{Effects on Population Features of Alfalfa}

The plant heights of AM were the lowest in the monocultures during the growing period compared with WM and LM, and consistent differences emerged in the mixtures (Table 3). This finding implies that variety was a determinant of the plant height of alfalfa, as was discovered by Maamouri et al. [25] 
and Del Pozo et al. [31]. We speculated that the plant height of alfalfa was significantly affected by mixed sowing. At the earlier stage, plant heights were not significantly different among the mixtures for the same variety. However, at the later stage, sudangrass showed a stronger impact on the plant height of alfalfa than oat. These variable results might be attributable to differences in the growth rate of the forages. At the earlier growth stage, when all the species were small, the competitive influences of sudangrass and oat were not significant. However, sudangrass matured early and had higher and broader leaves than oat at the later stage, imposing stronger suppression on alfalfa with a greater light interception.

In terms of branch number, mixed sowing had a significant impact on alfalfa at the earlier stage. However, the influence of oat diminished over time, while sudangrass still had strong effects. Sudangrass had a stronger effect on the growth of alfalfa than oat, likely because sudangrass had a higher branching ability with a stronger competitiveness for light capture. Neighboring species began to alter the light interception capacity of the community as the mixture grew [32]. However, no significant difference was obtained among the varieties in monocultures, and this result agreed with those of Wang et al. [33].

The plant densities of alfalfa in the mixtures were not significantly different from each other during the same period, suggesting that mixed sowing did not engender a difference in plant density. The higher plant density in monocultures may be due to the higher sowing ratio of alfalfa. This finding indicates that the plant density was highly related to the sowing ratio [34].

While differences among varieties were found, mixed sowing with grass had greater impacts on the population features of alfalfa. Investigations into the performance of alfalfa populations, such as those examining plant height, branch number and plant density, contribute to the understanding of the effects of mixed sowing during the growing period.

\subsection{Effects on Community Characteristics}

In mixtures, grasses were the dominant species and alfalfa was a subordinate species due to their different growth habits and morphologies. The dominance of coverage might be related to the taller plant individuals and broader leaves of grass [35]. The canopy of alfalfa was influenced by the shading of grasses in mixtures or by the weeds in monocultures, mainly green bristle grass (Setaria viridis). With higher coverage than oat, sudangrass exhibited stronger light interception, resulting in a lower coverage proportion in alfalfa (Figure 2). In addition, the coverage proportion of alfalfa and weeds tended to increase with time as their plant individuals grew and their leaf areas expanded. However, no significant difference in coverage was found among all the treatments despite reducing seeding ratios. In this case, the sowing ratio may not be an influencing factor of coverage.

Earlier research reported that greater productivity by intercropping compared with monocultures can be explained by increased PAR intercepted by the crop canopy [36]. Legume-grass mixed sowing complicates the spatial structure of forage communities, resulting in dissimilarity in light interception within the crop canopy [37]. The canopy closure of tall-statured grass prompted a better utilization of available light than that by alfalfa. Therefore, insufficient illumination may be a major constraint of alfalfa growth in mixtures. The data presented in Table 4 showed that at the earlier growth stage, fast-growing sudangrass intercepted more solar radiation than oat. At the middle stage, sudangrass with a high seeding ratio had an overwhelming advantage for light interception. The effects of oat in mixtures and weeds in monocultures were not significantly different. No significant difference was detected between the mixtures and monocultures in the alfalfa canopy for the same variety at the later stage, regardless of the sowing ratio. This might be because growing weeds had the same effect on solar radiation in the alfalfa canopy as the sown grass species at the later stage. Thus, appropriate canopy management is needed to maintain light competition between alfalfa and companion forage without reduced productivity [38]. Further investigations into the efficiency of light energy utilization under different intercropping patterns would be desirable to design more efficient intercropping systems. 
Community density can affect canopy architecture, influencing light interception, interspecific competition, plant growth and ultimately the biomass accumulation of the community [39]. In our study, the increase in community density in mixtures with oat indicated the tillering and growth of plant individuals. The reduction in community density in mixtures with sudangrass at the later stage may be due to the first harvest of sudangrass that decreased the number of sudangrass individuals. Community density displayed no response to the increased sowing ratios of grass. Productivity stability and ecological stability are the fundamental goals of cultivated pastures. Mixtures exhibited higher average productivity stability in our study (Table 5), corroborating the hypothesis that species diversity tends to enhance biomass stability in multispecies communities due to the complementary use of resources [40].

\subsection{Responses of Dry Matter Biomass}

Figure 1 shows that grasses were dominant in DM among mixtures, even with a lower sowing ratio and that sudangrass outcompeted oat. Even in monocultures, the DM proportion of weeds exceeded that of alfalfa. The sequences of DM proportion and coverage proportion among the three varieties in monocultures were the same (Figures 1 and 2), indicating that coverage was positively correlated with biomass [41]. Furthermore, a similar performance was found in plant height: AM had the lowest plant height compared with WM and LM (Table 3). We can infer from the findings above that variety was the determinant of the plant morphology of alfalfa and its contribution to the community in monocultures. However, the inconsistent variation between plant density and DM (Tables 2 and 3) agreed with previous research that yield did not respond proportionally to plant density [42].

Productivity is related to the intensity and form of a relationship between species in the community, which is either competitive or complementary with regard to resource utilization [43]. For short-season production, a high population increased canopy in the early growth stage, and the light interception rate was enhanced, which contributes to dry matter accumulation [44]. Although there was no significant difference in August, mixtures with sudangrass still outyielded monocultures because sudangrass was harvested twice, which explained the decline of DM in July (Table 2). Neugschwandtner and Kaul [35] reported that oat-pea intercropping failed to increase total grain yield in eastern Austria on fertile soil. Similar results were obtained in our study showing that the differences in DM between oat-alfalfa mixtures and alfalfa monocultures were not significant in most cases (Table 2). Consequently, legume-grass intercropping facilitated the production of desirable forages, which contributes to livestock production. Although the proportion of weeds tended to increase with time, legume-grass mixed sowing still stabilized the composition of DM to control the invasion by unplanted and less palatable species.

\subsection{Species Interactions}

The plant density, coverage proportion, community density, DM and biomass proportion of the alfalfa varieties in monocultures tended to rise with time and then fall (Tables 2-4; Figures 1 and 2). These findings indicated that the growth performance of alfalfa peaked at the middle stage, while weeds became competitive at the later stage. Taller plant individuals of fast-growing weeds might have engendered poor light penetration, resulting in the suppression of alfalfa growth, which ultimately led to reduced biomass [45]. Ball et al. [44] reported that increased species numbers improved productivity per unit but reduced yield per plant. Likewise, this was reflected in a higher total DM but lower plant height of alfalfa in mixtures compared to monocultures.

The process of plant community growth and production are essentially driven by niche complementarity and interspecific competition, which is highly associated with species functional traits variation in the community [46]. In our study, the complementary features in morphology and ecological functions between sudangrass and alfalfa prompted wider functional space in the intercropping communities, improving productivity. Our results revealed that at the earlier stage, the 
population features of alfalfa in mixtures were mainly determined by the alfalfa variety. However, interspecific competition between grass and alfalfa became dominant at the later stage. The effect of biodiversity experiences a transition from selection effect to niche complementarity [47].

Unseeded and less palatable species such as green bristle grass were common in legume-based grassland in this region. Weeds compete with alfalfa for light, nutrients and water, and they reduce forage quality as well [48]. However, oat and sudangrass are weed-suppressive species that thrive in interspecific competition [49]. Figures 1 and 2 revealed that mixed sowing reduced the coverage and DM proportion of weeds, leading to the conclusion that increased functional groups enhanced resistance to weeds [18]. Thus, alfalfa-legume intercropping could contribute to intensive agroecological management strategies by reducing the need for herbicides and mitigating environmental impacts [50].

Cultivated pasture is essential to ecological restoration and sustainable agriculture in the MBS. An appropriate combination of forage species with complementary traits can benefit livestock and herdsmen, as well as conserving the natural rangeland by decreasing grazing pressure with higher productivity. Meanwhile, increased forage production could make up the insufficiency of available forage in the desert regions of the MBS in the winter. This low-input forage cropping system provides beneficial ecosystems services, at least in the short term, and it could be the first step of cultivated pasture development strategy for China based on current social-economic conditions [51].

\section{Conclusions and Implications}

This study revealed optimized intercropping systems of cultivated pastures in the mountain-basin systems of northwest China. We found that alfalfa-annual grass intercropping tended to increase the production ability and ecological functions in the MBS. The plant traits of alfalfa in mixtures were determined by variety at the earlier stage and affected by the companion grass at the later growth stage. Forage grasses inhibited the performance of alfalfa in mixtures in comparison with monocultures, and sudangrass displayed a stronger inhibiting effect than oat. The suppression by grasses impaired the growth of alfalfa in terms of plant height, branch number, light reception and biomass accumulation. Although the suppression effect of weeds tended to rise with time, alfalfa-grass intercropping enhanced the resistance to weeds compared with monocropping. The results advance our understanding of the growth responses of alfalfa to intercropping during the first growing season in arid regions and provided insights into interspecific interactions between alfalfa and annual forage grass. In conclusion, the promotion of combining alfalfa and annual forage grass, especially sudangrass, on small-hold farms in the MBS is advocated. This alternative strategy shows not only yield advantages over monocrops but also ecological benefits to preserving natural pastures in the MBS.

Companion crops such as oat and sudangrass increased the forage yield of alfalfa pastures in the first year. In our study, alfalfa-grass intercropping was proven to be a promising cropping practice to prevent weed infestation. Therefore, based on the current cropping system, from the perspectives of yield, production stability and weed control, planting the variety leafy king or WL354HQ with sudangrass could be considered as a strategy to balance the goals of forage yield and ecological functions of cultivated pastures in the MBS (Figure A4). However, the results could vary under dissimilar field conditions, such as soil properties and local climate disturbance. Adequate irrigation as well as grazing exclusion should be taken into account in agronomic management. To obtain better alfalfa-grass intercropping systems in the MBS, future studies should focus on the effects of various sowing ratios and other companion grass species.

Author Contributions: Conceptualization, Y.F., B.L. and L.M.; validation, X.D. and X.B.; formal analysis, Y.F. and X.T.; investigation, Y.F., X.D. and L.M.; data curation, Y.F. and X.D.; writing-original draft, Y.F.; writing-review and editing, Y.F. and B.L.; visualization, X.T. and Z.Y.; project administration, Y.F.; funding acquisition, B.L.; supervision, B.L. and X.Z. All authors have read and agreed to the published version of the manuscript.

Funding: This research received financial support from the National Natural Science Foundation of China (No. 42071228) and the National Science and Technology Planning Project of China (No. 2014BAC15B04). 
Acknowledgments: The authors acknowledge the support of the Fuyun Grassland Station and the government of Dure Town for providing the demonstration field and helping with the agronomic management. We would like to thank Bo Nan and Haijiao Yu for their help with the field work.

Conflicts of Interest: The authors declare no conflict of interest.

\section{Appendix A}

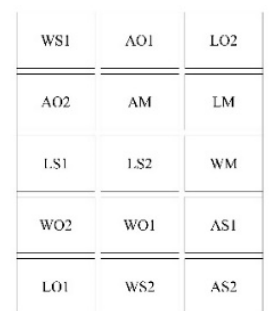

\begin{tabular}{c|c||c|} 
AO1 & AO2 & LO1 \\
\hline \hline AS1 & LO2 & AM \\
WS2 & 1.S1 & AS2 \\
\hline WO1 & LM & WM \\
\hline \hline WO2 & WS1 & LS2 \\
\hline \hline
\end{tabular}

\begin{tabular}{|c||c|c} 
LS2 & WM & AS2 \\
\hline \hline LM & WS2 & WO1 \\
AO2 & W02 & 1.01 \\
\cline { 1 - 1 } AM & AO1 & AS1 \\
\hline \hline WS1 & LO2 & LS1 \\
\hline
\end{tabular}

\begin{tabular}{|c||cc|} 
AO1 & WO1 & A.M \\
\hline \hline L.M & AO2 & LO2 \\
LS1 & WM & LS2 \\
\hline \hline WS2 & AS1 & WS1 \\
LO1 & WO2 & AS2 \\
\hline
\end{tabular}

\begin{tabular}{c|c|c}
\hline WM & LO1 & LS1 \\
LO2 & WS2 & WO2 \\
\hline \hline AS1 & AM & W01 \\
\hline AO2 & AS2 & LS2 \\
\hline AO1 & LM & WS1 \\
\hline
\end{tabular}

Figure A1. The field design diagrams of the experiments. The abbreviations are the same as above.

\section{Appendix B}

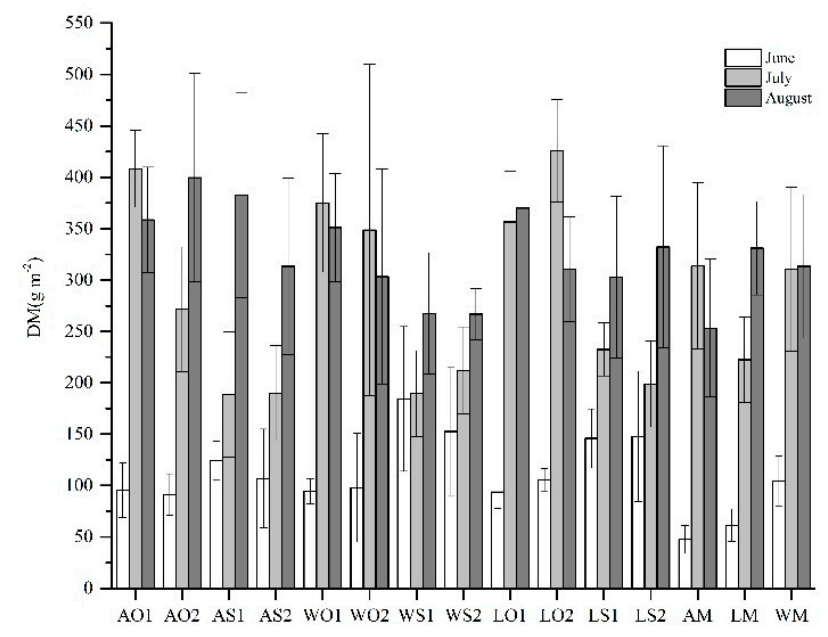

Figure A2. The DM among all treatments during the growing season (mean $\pm \mathrm{SD}$ ). The abbreviations are the same as above. 


\section{Appendix C}

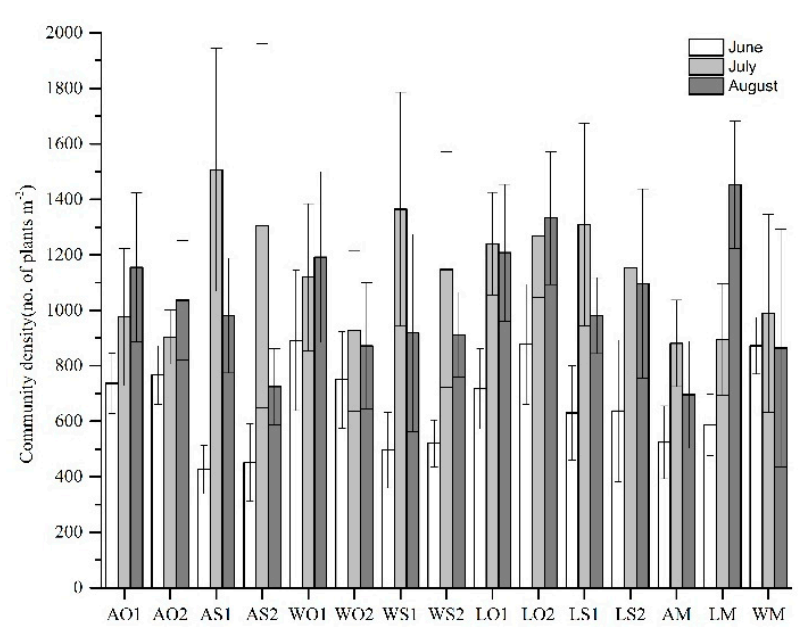

Figure A3. The community density among all treatments during the growing season (mean $\pm \mathrm{SD}$ ). The abbreviations are the same as above.

\section{Appendix D}
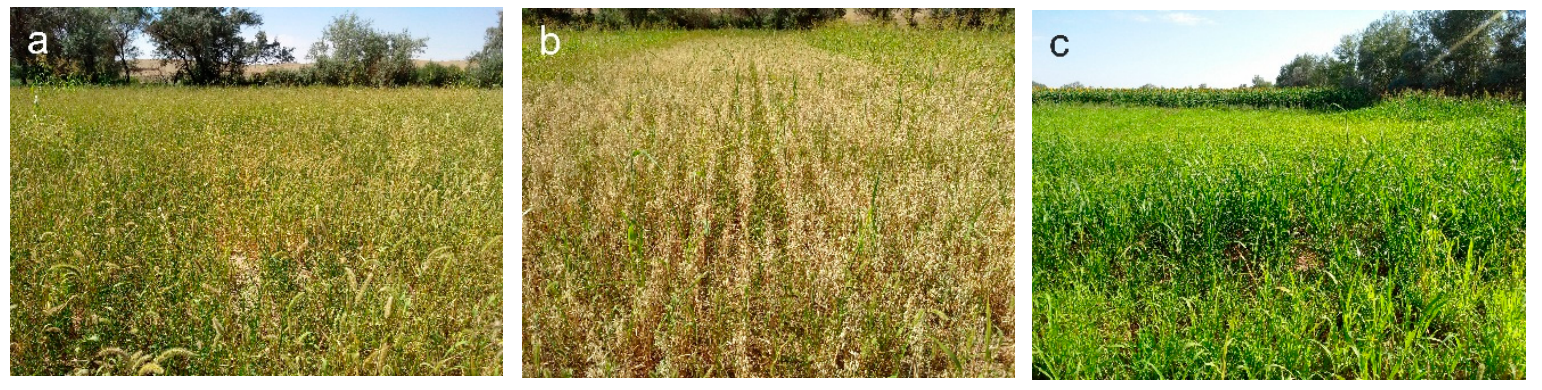

Figure A4. Representative pictures of alfalfa monocrop (a), alfalfa/oat intercrops (b) and alfalfa/sudangrass intercrops (c).

\section{References}

1. Bi, X.; Li, B.; Fu, Q.; Fan, Y.; Ma, L.; Yang, Z.; Nan, B.; Dai, X.; Zhang, X. Effects of grazing exclusion on the grassland ecosystems of mountain meadows and temperate typical steppe in a mountain-basin system in Central Asia's arid regions, China. Sci. Total Environ. 2018, 630, 254-263. [CrossRef] [PubMed]

2. Zhang, X. Ecological restoration and sustainable agricultural paradigm of mountain-oasis-ecotone-desert system in the north of the Tianshan Mountains. Acta Bot. Sin. 2001, 43, 1294-1299.

3. Fu, Q.; Li, B.; Yang, L.; Wu, Z.; Zhang, X. Ecosystem services evaluation and its spatial characteristics in central Asia's Arid Regions: A case study in Altay Prefecture, China. Sustainability 2015, 7, 8335-8353. [CrossRef]

4. Li, W.; Wang, J.; Zhang, X.; Shi, S.; Cao, W. Effect of degradation and rebuilding of artificial grasslands on soil respiration and carbon and nitrogen pools on an alpine meadow of the Qinghai-Tibetan Plateau. Ecol. Eng. 2018, 111, 134-142. [CrossRef]

5. Loucougaray, G.; Dobremez, L.; Gos, P.; Pauthenet, Y.; Nettier, B.; Lavorel, S. Assessing the effects of grassland management on forage production and environmental quality to identify paths to ecological intensification in mountain grasslands. Environ. Manag. 2015, 56, 1039-1052. [CrossRef]

6. Annicchiarico, P.; Pecetti, L.; Abdelguerfi, A.; Bouizgaren, A.; Carroni, A.M.; Hayek, T.; Bouzina, M.M.H.; Mezni, M. Adaptation of landrace and variety germplasm and selection strategies for lucerne in the Mediterranean basin. Field Crop. Res. 2011, 120, 283-291. [CrossRef] 
7. Coruh, I.; Tan, M. The effects of seeding time and companion crop on yield of alfalfa (Medicago sativa L.) and weed growth. Turk. J. Field Crops 2016, 21, 184-189. [CrossRef]

8. Orlandi Laureto, L.M.; Cianciaruso, M.V.; Menezes Samia, D.S. Functional diversity: An overview of its history and applicability. Nat. Conserv. 2015, 13, 112-116. [CrossRef]

9. Goslee, S.C.; Veith, T.L.; Skinner, R.H.; Comas, L.H. Optimizing ecosystem function by manipulating pasture community composition. Basic Appl. Ecol. 2013, 14, 630-641. [CrossRef]

10. Dunea, D.; Dinca, N. Improving land utilization using intensive grass-clover mixtures in forage production systems. Rom. Agric. Res. 2014, 31, 147-158.

11. Skinner, R.H.; Dell, C.J. Yield and soil carbon sequestration in grazed pastures sown with two or five forage species. Crop Sci. 2016, 56, 2035-2044. [CrossRef]

12. Finger, R.; Buchmann, N. An ecological economic assessment of risk-reducing effects of species diversity in managed grasslands. Ecol. Econ. 2015, 110, 89-97. [CrossRef]

13. Barkaoui, K.; Roumet, C.; Volaire, F. Mean root trait more than root trait diversity determines drought resilience in native and cultivated Mediterranean grass mixtures. Agric. Ecosyst. Environ. 2016, 231, 122-132. [CrossRef]

14. Dordas, C.A.; Vlachostergios, D.N.; Lithourgidis, A.S. Growth dynamics and agronomic-economic benefits of pea-oat and pea-barley intercrops. Crop Pasture Sci. 2012, 63, 45-52. [CrossRef]

15. Albayrak, S.; Turk, M. Changes in the forage yield and quality of legume-grass mixtures throughout a vegetation period. Turk. J. Agric. For. 2013, 37, 139-147. [CrossRef]

16. Atienza, S.G.; Rubiales, D. Legumes in sustainable agriculture. Crop Pasture Sci. 2017, 68. [CrossRef]

17. Duchene, O.; Vian, J.; Celette, F. Intercropping with legume for agroecological cropping systems: Complementarity and facilitation processes and the importance of soil microorganisms. A. review. Agric. Ecosyst. Environ. 2017, 240, 148-161. [CrossRef]

18. Vrignon-Brenas, S.; Celette, F.; Piquet-Pissaloux, A.; Corre-Hellou, G.; David, C. Intercropping strategies of white clover with organic wheat to improve the trade-off between wheat yield, protein content and the provision of ecological services by white clover. Field Crop. Res. 2018, 224, 160-169. [CrossRef]

19. Pelzer, E.; Bourlet, C.; Carlsson, G.; Lopez-Bellido, R.J.; Jensen, E.S.; Jeuffroy, M.H. Design, assessment and feasibility of legume-based cropping systems in three European regions. Crop Pasture Sci. 2017, 68, 902-914. [CrossRef]

20. Luo, C.; Wang, S.; Zhao, L.; Xu, S. Seeding ratios and phosphate fertilizer on ecosystem carbon exchange of common vetch and oat. Nutr. Cycl. Agroecosys. 2017, 109, 149-160. [CrossRef]

21. Van Eekeren, N.; Bos, M.; de Wit, J.; Keidel, H.; Bloem, J. Effect of individual grass species and grass species mixtures on soil quality as related to root biomass and grass yield. Appl. Soil Ecol. 2010, 45, 275-283. [CrossRef]

22. Sturludóttir, E.; Brophy, C.; Bélanger, G.; Gustavsson, A.M.; Jørgensen, M.; Lunnan, T.; Helgadóttir, Á. Benefits of mixing grasses and legumes for herbage yield and nutritive value in Northern Europe and Canada. Grass Forage Sci. 2014, 69, 229-240. [CrossRef]

23. Hayes, R.C.; Li, G.D.; Sandral, G.A.; Swan, T.D.; Price, A.; Hildebrand, S.; Goward, L.; Fuller, C.; Peoples, M.B. Enhancing composition and persistence of mixed pasture swards in southern New South Wales through alternative spatial configurations and improved legume performance. Crop Pasture Sci. 2017, 68, 1112-1130. [CrossRef]

24. Maamouri, A.; Louarn, G.T.; Béguier, V.; Julier, B. Performance of lucerne genotypes for biomass production and nitrogen content differs in monoculture and in mixture with grasses and is partly predicted from traits recorded on isolated plants. Crop Pasture Sci. 2017, 68, 942-951. [CrossRef]

25. Maamouri, A.; Louarn, G.T.; Gastal, F.O.B.; Guier, V.; Julier, B. Effects of lucerne genotype on morphology, biomass production and nitrogen content of lucerne and tall fescue in mixed pastures. Crop Pasture Sci. 2015, 66, 192-204. [CrossRef]

26. Husse, S.; Huguenin-Elie, O.; Buchmann, N.; Lüscher, A. Larger yields of mixtures than monocultures of cultivated grassland species match with asynchrony in shoot growth among species but not with increased light interception. Field Crop. Res. 2016, 194, 1-11. [CrossRef]

27. Ponisio, L.; Ehrlich, P. Diversification, yield and a new agricultural revolution: Problems and prospects. Sustainability 2016, 8, 1118. [CrossRef] 
28. Lamb, J.F.S.; Jung, H.G.; Riday, H. Growth environment, harvest management and germplasm impacts on potential ethanol and crude protein yield in alfalfa. Biomass Bioenergy 2014, 63, 114-125. [CrossRef]

29. Annicchiarico, P.; Alami, I.T.; Abbas, K.; Pecetti, L.; Melis, R.A.M.; Porqueddu, C. Performance of legume-based annual forage crops in three semi-arid Mediterranean environments. Crop Pasture Sci. 2017, 68, 932-941. [CrossRef]

30. Lehman, C.L.; Tilman, D. Biodiversity, stability, and productivity in competitive communities. Am. Nat. 2000, 156, 534-552. [CrossRef]

31. Del Pozo, A.; Ovalle, C.; Espinoza, S.; Barahona, V.; Gerding, M.; Humphries, A. Water relations and use-efficiency, plant survival and productivity of nine alfalfa (Medicago sativa L.) cultivars in dryland Mediterranean conditions. Eur. J. Agron. 2017, 84, 16-22. [CrossRef]

32. Barillot, R.; Escobar-Gutiérrez, A.J.; Fournier, C.; Huynh, P.; Combes, D. Assessing the effects of architectural variations on light partitioning within virtual wheat-pea mixtures. Ann. Bot. 2014, 114, 725-737. [CrossRef] [PubMed]

33. Wang, Y.; Li, D.; Qi, S.; Wang, C.; Gao, Y.; Zheng, C.; Li, P. Effects of seeding rate and variety on branch number and plant height of alfalfa. Acta Pratac. Sin. 2017, 26, 183-190. [CrossRef]

34. Zarza, R.; Rebuffo, M.; La Manna, A.; Balzarini, M. Plant density in red clover (Trifolium pratense L.) pastures as an early predictor of forage production. Eur. J. Agron. 2018, 101, 193-199. [CrossRef]

35. Neugschwandtner, R.W.; Kaul, H. Sowing ratio and N fertilization affect yield and yield components of oat and pea in intercrops. Field Crop. Res. 2014, 155, 159-163. [CrossRef]

36. Gou, F.; van Ittersum, M.K.; Simon, E.; Leffelaar, P.A.; van der Putten, P.E.L.; Zhang, L.; van der Werf, W. Intercropping wheat and maize increases total radiation interception and wheat RUE but lowers maize RUE. Eur. J. Agron. 2017, 84, 125-139. [CrossRef]

37. Niklaus, P.A.; Baruffol, M.; He, J.S.; Ma, K.; Schmid, B. Can niche plasticity promote biodiversity-productivity relationships through increased complementarity? Ecology 2017, 98, 1104-1116. [CrossRef]

38. Querné, A.; Battie-laclau, P.; Dufour, L.; Wery, J.; Dupraz, C. Effects of walnut trees on biological nitrogen fixation and yield of intercropped alfalfa in a Mediterranean agroforestry system. Eur. J. Agron. 2017, 84, 35-46. [CrossRef]

39. Yang, G.; Luo, X.; Nie, Y.; Zhang, X. Effects of plant density on yield and canopy micro environment in hybrid cotton. J. Integr. Agr. 2014, 13, 2154-2163. [CrossRef]

40. Gross, K.; Cardinale, B.J.; Fox, J.W.; Gonzalez, A.; Loreau, M.; Polley, H.W.; Reich, P.B.; van Ruijven, J. Species richness and the temporal stability of biomass production: A new analysis of recent biodiversity experiments. Am. Nat. 2014, 183, 1-12. [CrossRef]

41. Sanaei, A.; Ali, A.; Chahouki, M.A.Z. The positive relationships between plant coverage, species richness, and aboveground biomass are ubiquitous across plant growth forms in semi-steppe rangelands. J. Environ. Manag. 2018, 205, 308-318. [CrossRef] [PubMed]

42. Hakl, J.; Pisarčik, M.; Hrevušová, Z.; Šantrůček, J. In-field lucerne root morphology traits over time in relation to forage yield, plant density, and root disease under two cutting managements. Field Crop. Res. 2017, 213, 109-117. [CrossRef]

43. Mischkolz, J.M.; Schellenberg, M.P.; Lamb, E.G. Assembling productive communities of native grass and legume species: Finding the right mix. Appl. Veg. Sci. 2016, 19, 111-121. [CrossRef]

44. Ball, R.A.; Purcell, L.C.; Vories, E.D. Short-season soybean yield compensation in response to population and water regime. Crop Sci. 2000, 40, 1070-1078. [CrossRef]

45. Baraibar, B.; Hunter, M.C.; Schipanski, M.E.; Hamilton, A.; Mortensen, D.A. Weed suppression in cover crop monocultures and mixtures. Weed Sci. 2018, 66, 121-133. [CrossRef]

46. Wagg, C.; Ebeling, A.; Roscher, C.; Ravenek, J.; Bachmann, D.; Eisenhauer, N.; Mommer, L.; Buchmann, N.; Hillebrand, H.; Schmid, B.; et al. Functional trait dissimilarity drives both species complementarity and competitive disparity. Funct. Ecol. 2017, 31, 2320-2329. [CrossRef]

47. Li, A.; Niu, K.; Du, G. Resource availability, species composition and sown density effects on productivity of experimental plant communities. Plant Soil 2011, 344, 177-186. [CrossRef]

48. Pacanoski, Z.; Týr, S.; Vereš, T. Weed control in dormant alfalfa (Medicago sativa L.) with active ingredients' metribuzin, imazetapyr and pronamide. J. Cent. Eur. Agric. 2017, 18, 42-54. [CrossRef]

49. Holmes, A.A.; Thompson, A.A.; Wortman, S.E. Species-specific contributions to productivity and weed suppression in cover crop mixtures. Agron. J. 2017, 109, 2808-2819. [CrossRef] 
50. Barilli, E.; Jeuffroy, M.H.; Gall, J.; de Tourdonnet, S.; Mediene, S. Weed response and crop growth in winter wheat-lucerne intercropping: A comparison of conventional and reduced soil-tillage conditions in northern France. Crop Pasture Sci. 2017, 68, 1070-1079. [CrossRef]

51. Chen, H.; He, L.; Tang, H.; Zhao, M.; Shao, L. A two-step strategy for developing cultivated pastures in China that offer the advantages of ecosystem services. Sustainability 2016, 8, 392. [CrossRef] 